\title{
Three-Dimensional Animation of Human Blood Circulation System Using High Poly and Particle System Techniques
}

\author{
Nurcahyani Dewi Retnowati ${ }^{1}$, Sudaryanto ${ }^{2}$, Alfian Herianto ${ }^{3}$ \\ Program Studi Teknik Informatika \\ Sekolah Tinggi Teknologi Adisutjipto \\ Jl. Blok R Adisucipto Banguntapan Yogyakarta \\ ndewiret@gmail.com ${ }^{1}$,sudaryanto@stta.ac.id², alvianherianto09@gmail.com ${ }^{3}$
}

\begin{abstract}
Circulatory system learning can use three-dimensional animation technology to facilitate the delivery of material in teaching and learning activities in elementary schools. In making the three-dimensional animation using Autodesk Maya software and 3Ds Max software. The techniques used include High Poly techniques and Particle System techniques. Heart and lung organs, visualized in three dimensions using High Poly techniques while animation of circulatory systems in humans using Particle System techniques. The application function test results indicate that this application can run according to its function and the results of testing the use of applications with the teacher respondents with calculations using a Likert scale obtained results of $97.2 \%$ and these results fall into the very good category (using the calculation of interval formulas), so that conclusions are obtained that the three-dimensional animation application of the circulatory system can be applied and can assist the teacher in providing student learning in elementary school.
\end{abstract}

Keywords : three-dimensional animation, high poly, particle system

\begin{abstract}
Abstrak
Pembelajaran sistem peredaran darah dapat menggunakan teknologi animasi tiga dimensi untuk memudahkan penyampaian materi pada kegiatan belajar mengajar di sekolah dasar. Dalam pembuatan animasi tiga dimensi tersebut menggunakan software Autodesk Maya dan software 3Ds Max. Teknik yang digunakan antara lain teknik High Poly dan teknik Particle System. Organ jantung dan paru-paru, divisualisasikan secara tiga dimensi dengan menggunakan teknik High Poly sedangkan animasi sistem peredaran darah pada manusia menggunakan teknik Particle System. Hasil uji fungsi aplikasi menunjukkan bahwa aplikasi ini dapat berjalan sesuai fungsinya dan hasil uji penggunaan aplikasi dengan responden Guru dengan perhitungan menggunakan skala Likert didapatkan hasil sebesar 97,2\% dan hasil tersebut masuk dalam kategori sangat baik (menggunakan perhitungan rumus interval), sehingga didapatkan kesimpulan bahwa aplikasi animasi tiga dimensi sistem peredaran darah ini dapat diterapkan dan dapat membantu Guru dalam memberikan pembelajaran siswa di sekolah dasar.
\end{abstract}

Kata Kunci: animasi tiga dimensi, high poly, particle system

\section{PENGANTAR}

Teknologi yang semakin berkembang dapat membantu dalam peningkatan pembelajaran. Teknologi tersebut dapat berupa animasi tiga dimensi. Animasi adalah rangkaian gambar yang membentuk sebuah gerakan. Salah satu keunggulan animasi dibanding media lain seperti gambar statis atau teks adalah kemampuannya untuk menjelaskan perubahan keadaan tiap waktu [1]. Animasi tiga dimensi adalah pengembangan dari animasi dua dimensi. Animasi dua dimensi merupakan teknik pembuatan animasi dengan menggunakan gambar bersumbu (axis) dua yaitu X dan Y [2]. Objek tiga dimensi 
mempunyai bentuk, volume, dan ruang. Sehingga objek tersebut memiliki koordinat X, Y, dan Z. Jika pada animasi dua dimensi, objek hanya dapat digerakkan ke dua arah, yaitu ke kanan - kiri (X) dan atas - bawah (Y). Pada animasi tiga dimensi, objek dapat digerakkan ke tiga arah, yaitu ke kanan - kiri (X), atas - bawah (Y) dan depan - belakang (Z) [3].

Salah satu pembelajaran yang dapat diimplementasikan dengan multimedia interaktif adalah tentang sistem peredaran darah manusia. Dalam pembelajaran tersebut dapat dijelaskan mengenai fungsi masing-masing organ yang berperan penting dalam sistem peredaran darah manusia. Organ-organ yang terlibat dalam sistem peredaran darah manusia antara lain jantung dan paru-paru. Dalam pembuatan animasi tiga dimensi sistem peredaran darah manusia menggunakan software Autodesk Maya dan software 3Ds Max. Teknik yang digunakan ada 2 macam yaitu teknik High Poly dan teknik Particle System. Organ jantung dan paru-paru, divisualisasikan secara tiga dimensi dengan menggunakan teknik High Poly sedangkan animasi sistem peredaran darah pada manusia menggunakan teknik Particle System.

Particle system adalah sebuah teknik untuk pemodelan sebuah kelas dari objek fuzzy, particle adalah objek yang mempunyai massa, posisi, percepatan dan respon terhadap gaya, tetapi tidak memiliki batas ruang. Karena karakteristiknya yang sederhana sejauh ini partikel adalah objek yang paling mudah untuk simulasi [4].

High Poly adalah suatu teknik pemodelan yang menggunakan banyak poligon atau jumlah poligon tinggi dengan kisaran ribuan bahkan ratusan ribu poligon sehingga dapat dilihat dengan detail suatu objek [5]. Penggunaan teknik high poly dapat mempermudah dalam koreksi pemodelan dan kualitas yang dihasilkan juga lebih baik.

\section{Metodologi Penelitian}

Metodologi penelitian yang digunakan dalam pembuatan animasi 3D organ yang berfungsi dalam sistem peredaran darah manusia dan pembuatan animasi tiga dimensi.

\subsection{Metode Analisis Data}

Dalam metode analisis data dimulai dari penentuan spesifikasi hardware dan software yang digunakan dalam proses pembuatan, kemudian dilanjutkan dengan perancangan flowchart atau diagram alur menggunakan software Visio. Flowchart merupakan representasi visual urutan langkah dalam suatu proses. Setiap urutan langkah digambarkan dalam bentuk simbol-simbol diagram dan dihubungkan dengan garis dan arah panah dari mulai proses hingga proses selesai [4], dan perancangan tampilan. Perancangan flowchart sistem (alur kerja) dapat dilihat pada Gambar 1.

Alur kerja sistem ketika user atau pengguna aplikasi mulai masuk ke tampilan menu utama, dalam menu utama ada beberapa fitur-fitur yang tersedia diantaranya fitur jantung, fitur paru-paru, dan fitur Sistem Peredaran Darah (SPD). Dalam fitur jantung, aplikasi akan menampilkan jantung dalam bentuk animasi dengan penjelasan kinerja jantung dalam bentuk teks dan audio, sama halnya dalam fitur paru-paru. Aplikasi akan menampilkan model manusia serta pembuluh darah manusia dalam bentuk animasi dan Sistem Peredaran Darah (SPD) dalam tubuh manusia.

Proses produksi animasi melalui 3 tahapan yaitu proses pra produksi, produksi dan pasca produksi. Pada proses pra produksi meliputi penentuan konsep, skenario dan material collecting. Pada proses produksi terdapat proses desain dan modelling. Sedangkan pada proses pasca produksi terdapat proses assembly. Kesemua proses tersebut digambarkan seperti pada Gambar 2. 

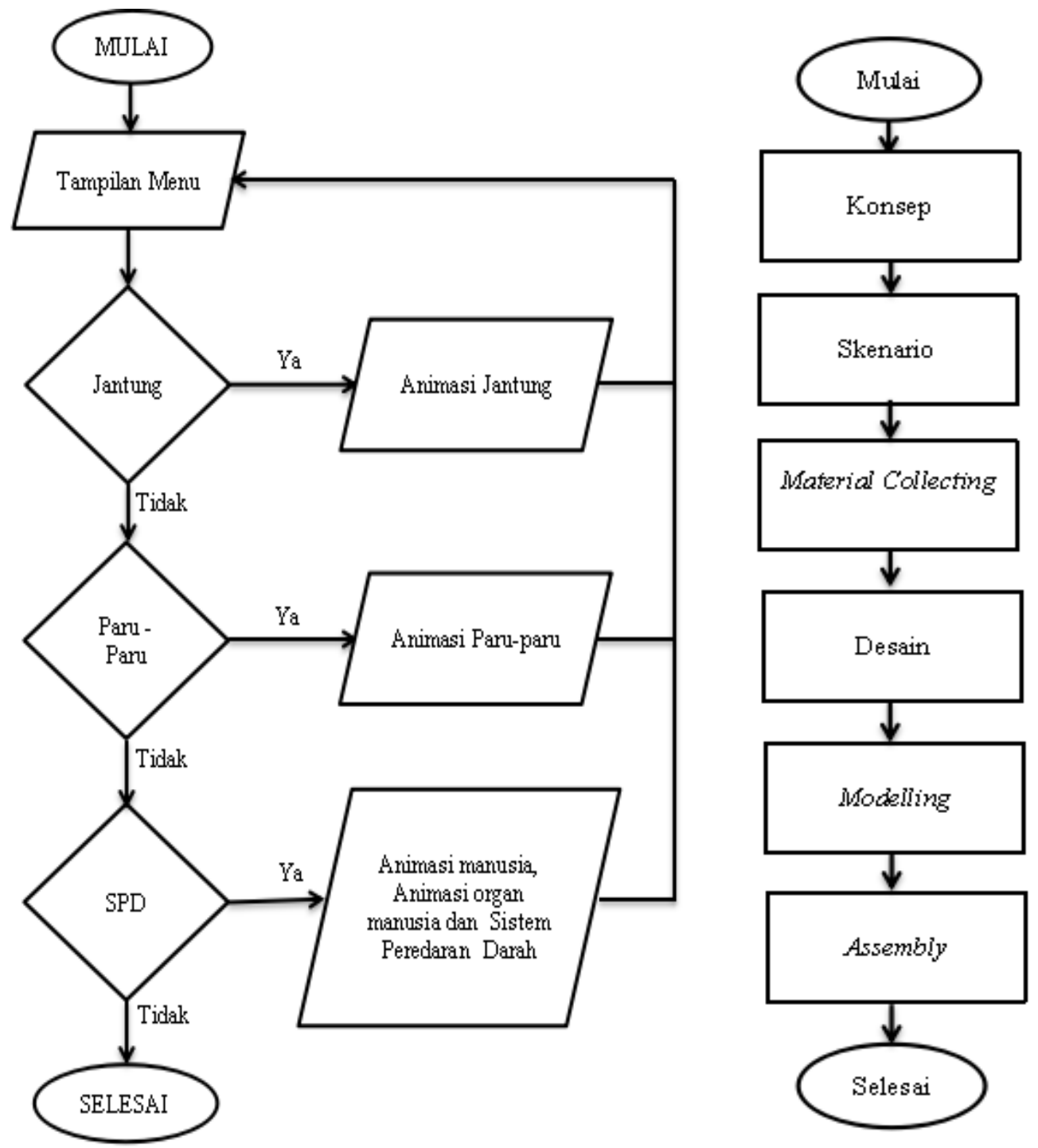

Gambar 1. Flowchart Aplikasi

Gambar 2. Tahapan Pembuatan.Animasi

Konsep atau pengonsepan menjelaskan tentang animasi apa yang akan dikerjakan. Termasuk di dalamnya konsep cerita (premis dan sinopsis), konsep style atau gaya animasi, konsep desain dan latar belakangnya [1]. Dalam tahapan konsep pada penelitian ini merupakan tahap untuk menentukan pengguna aplikasi, image, animasi, interaktivitas dan pemodelan 3D yang dijelaskan pada Tabel 1 .

Tabel 1. Konsep Animasi

\begin{tabular}{|l|l|}
\hline Pengguna & \multicolumn{1}{|c|}{ Pengajar atau Guru } \\
\hline Image & $\begin{array}{l}\text { Simbol-simbol berformat PNG yang dibuat } \\
\text { sendiri } \\
\text { Background yang berformat JPG yang dibuat } \\
\text { sendiri }\end{array}$ \\
\hline Animasi & $\begin{array}{l}\text { Efek transisi yang dibuat sendiri } \\
\text { Animasi tombol yang dibuat sendiri }\end{array}$ \\
\hline Interaktivitas & $\begin{array}{l}\text { Mouse over, link button, movie clip yang } \\
\text { bergerak continuos, dan animasi tombol yang } \\
\text { variatif }\end{array}$ \\
\hline Pemodelan 3D & $\begin{array}{l}\text { Pemodelan 3D dengan pilihan rotasi objek } \\
\text { yang bisa diatur }\end{array}$ \\
\hline
\end{tabular}


Skenario pada penelitian ini membahas tentang mekanisme atau cara kerja sistem serta tampilan aplikasi yang sudah dirancang dalam aplikasi pembelajaran animasi 3D peredaran darah manusia.

Material Collecting adalah tahap pengumpulan bahan dan pengelompokan bahan yang sesuai dengan kebutuhan rancangan.

Desain adalah tahapan pembuatan spesifikasi mengenai arsitektur program, gaya, tampilan, dan kebutuhan material/bahan untuk program. Jenis desain dalam tahap ini diantaranya adalah :

1. Desain gambar yang dibuat menjadi acuan dalam pembuatan model animasi tiga dimensi.

2. Desain struktur navigasi dapat dilihat dalam Tabel.2.

3. Desain berorientasi objek merupakan model animasi 3D yang sudah dibuat dimulai dari jantung, paru-paru, sel darah merah, saluran pembuluh darah, organ dalam tubuh manusia, dan tubuh manusia bagian luar.

Modeling adalah proses pembuatan model 3D yang akan dianimasikan, yang dibuat dengan teknik pemodelan high poly dan particle system.

Proses yang terakhir adalah tahapan Assembly yang merupakan tahap pembuatan/penyusunan dari bahan-bahan yang sudah disiapkan dari awal hingga akhir untuk dijadikan aplikasi yang akan menjadi proses akhir, dalam tahapan ini menggunakan software unity.

Tabel 2. Control Navigasi

\begin{tabular}{|c|c|}
\hline Visual & Keterangan \\
\hline Jantung & Button yang membawa user menuju content jantung. \\
\hline Paru-paru & Button yang membawa user menuju content paru-paru. \\
\hline SPD & $\begin{array}{l}\text { Button yang membawa user menuju content sistem } \\
\text { peredaran darah. }\end{array}$ \\
\hline $\mathbf{Y}$ & Heyperpicture yang membawa user menuju keluar aplikasi. \\
\hline Close & $\begin{array}{l}\text { Button yang membawa user kembali menuju content } \\
\text { halaman utama. }\end{array}$ \\
\hline & $\begin{array}{l}\text { Button untuk merotasi ke atas objek animasi } 3 \mathrm{D} \text { jantung, } \\
\text { paru-paru, dan organ tubuh manusia. }\end{array}$ \\
\hline & $\begin{array}{l}\text { Button untuk merotasi ke bawah objek animasi 3D jantung, } \\
\text { paru-paru, dan organ tubuh manusia. }\end{array}$ \\
\hline & $\begin{array}{l}\text { Button untuk merotasi ke kanan objek animasi 3D jantung, } \\
\text { paru-paru, dan organ tubuh manusia. }\end{array}$ \\
\hline & $\begin{array}{l}\text { Button untuk merotasi ke kiri objek animasi 3D jantung, } \\
\text { paru-paru, dan organ tubuh manusia. }\end{array}$ \\
\hline
\end{tabular}




\begin{tabular}{|l|l|}
\hline $\begin{array}{l}\text { Button untuk zoom out objek animasi 3D jantung, paru- } \\
\text { paru dan organ tubuh manusia. } \\
\text { dan organ tubuh manusia. }\end{array}$ \\
\hline
\end{tabular}

\subsection{Pemodelan}

Pemodelan yang dilakukan pada penelitian ini adalah membuat objek organ tubuh yang berfungsi pada sistem peredaran darah. Pemodelan yang pertama adalah dengan memuat objek jantung dengan menggunakan teknik high poly (Gambar 3). Pemodelan yang kedua adalah objek paru-paru dengan teknik yang sama, yaitu teknik high poly (Gambar 4). Untuk pemodelan objek sel darah merah (Gambar 5) menggunakan teknik yang berbeda, yaitu teknik particle system. Pemodelan objek organ dalam tubuh manusia (Gambar 6) dan objek tubuh manusia menggunakan teknik high poly. Teknik pemodelan penambahan titik garis berkualitas tinggi atau sering disebut high poly untuk mempermudah dalam pembentukan model yang dibuat. Model pembuluh darah dalam bentuk animasi tiga dimensi (Gambar 7) pembuatannya menggunakan software Autodesk Maya yang juga menggunakan teknik high poly untuk mempermudah membentuk lengkungan-lengkungan pada aliran pembuluh darah.

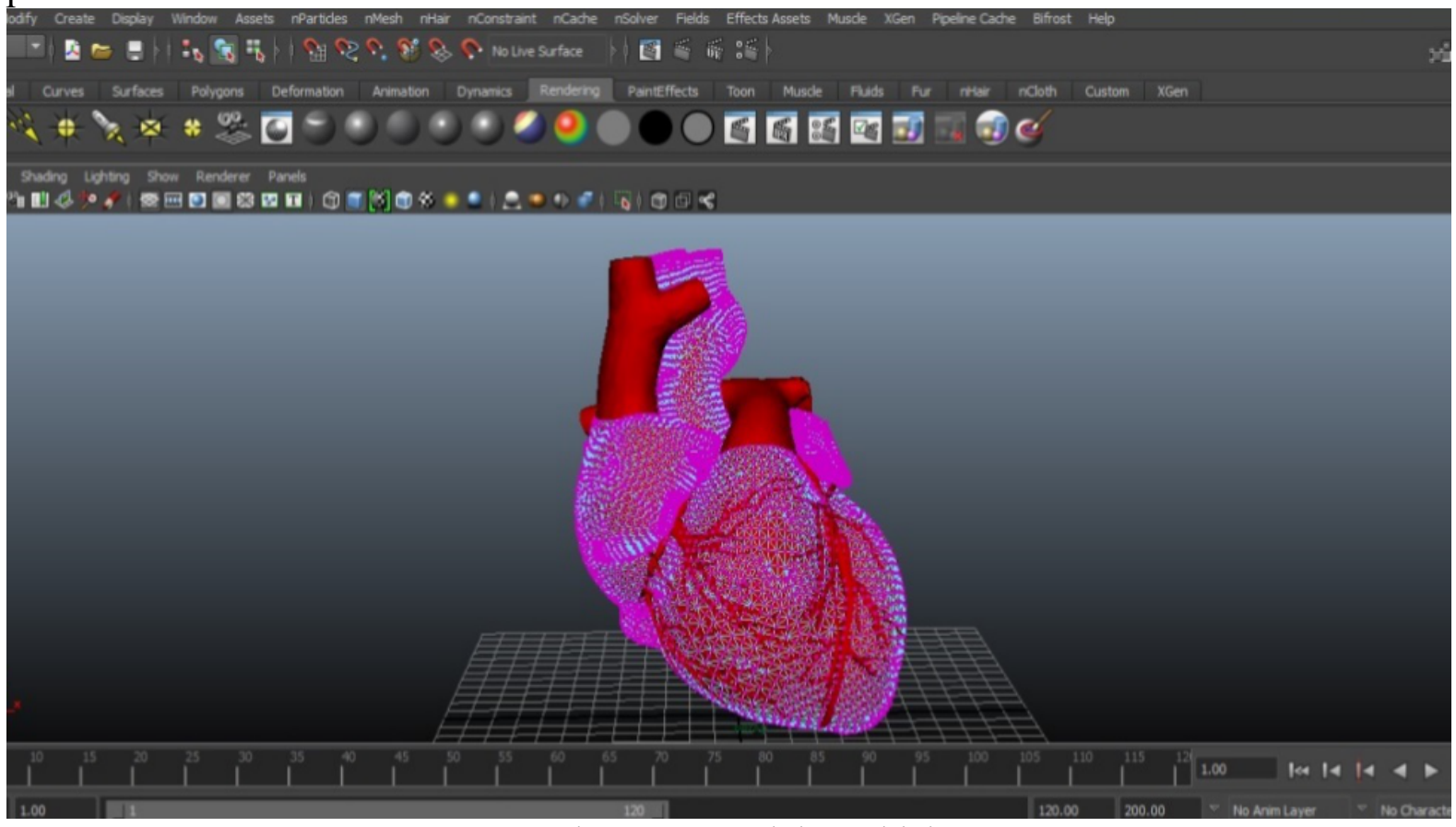

Gambar 3. Pemodelan Objek Jantung 


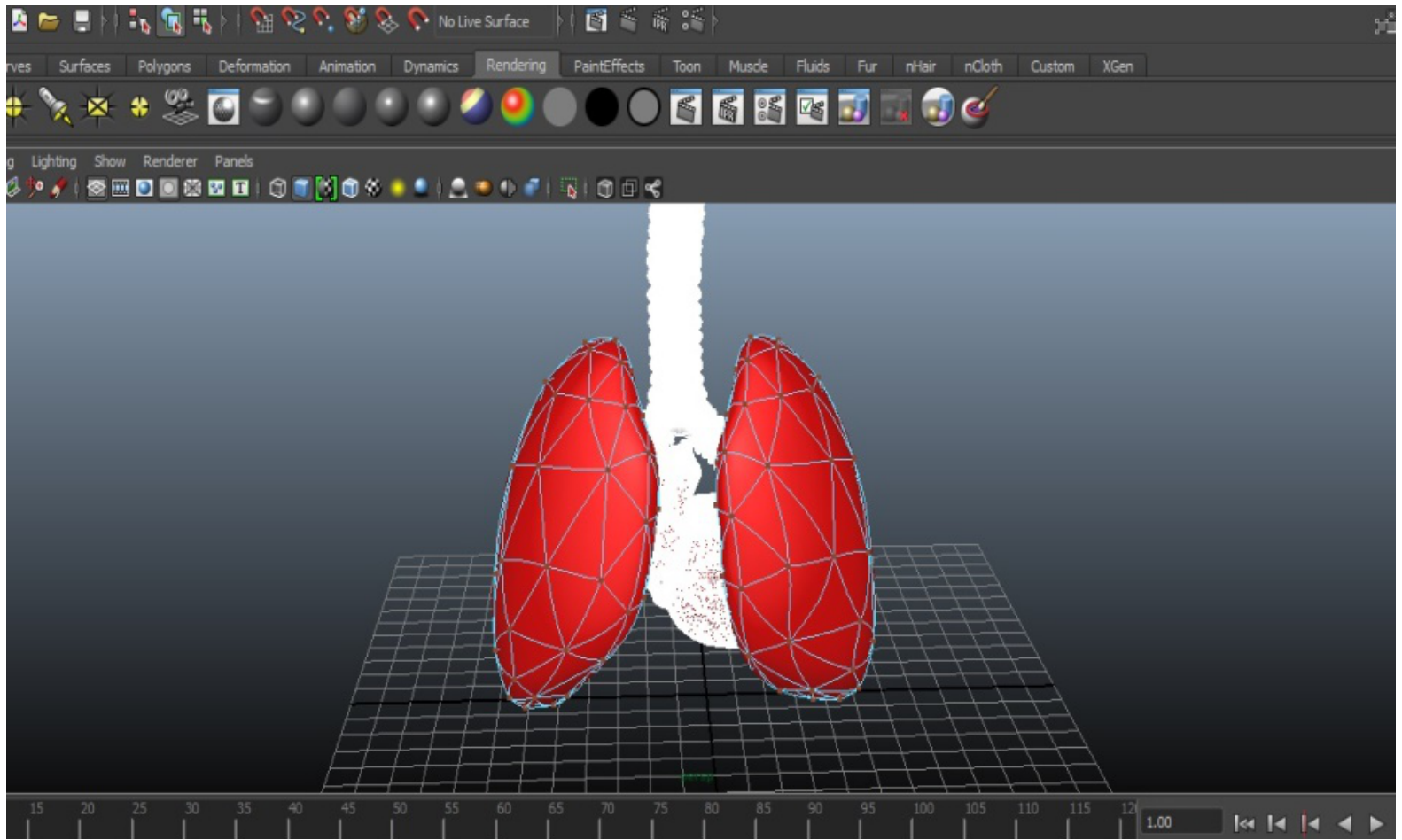

Gambar 4. Pemodelan Objek Paru-Paru

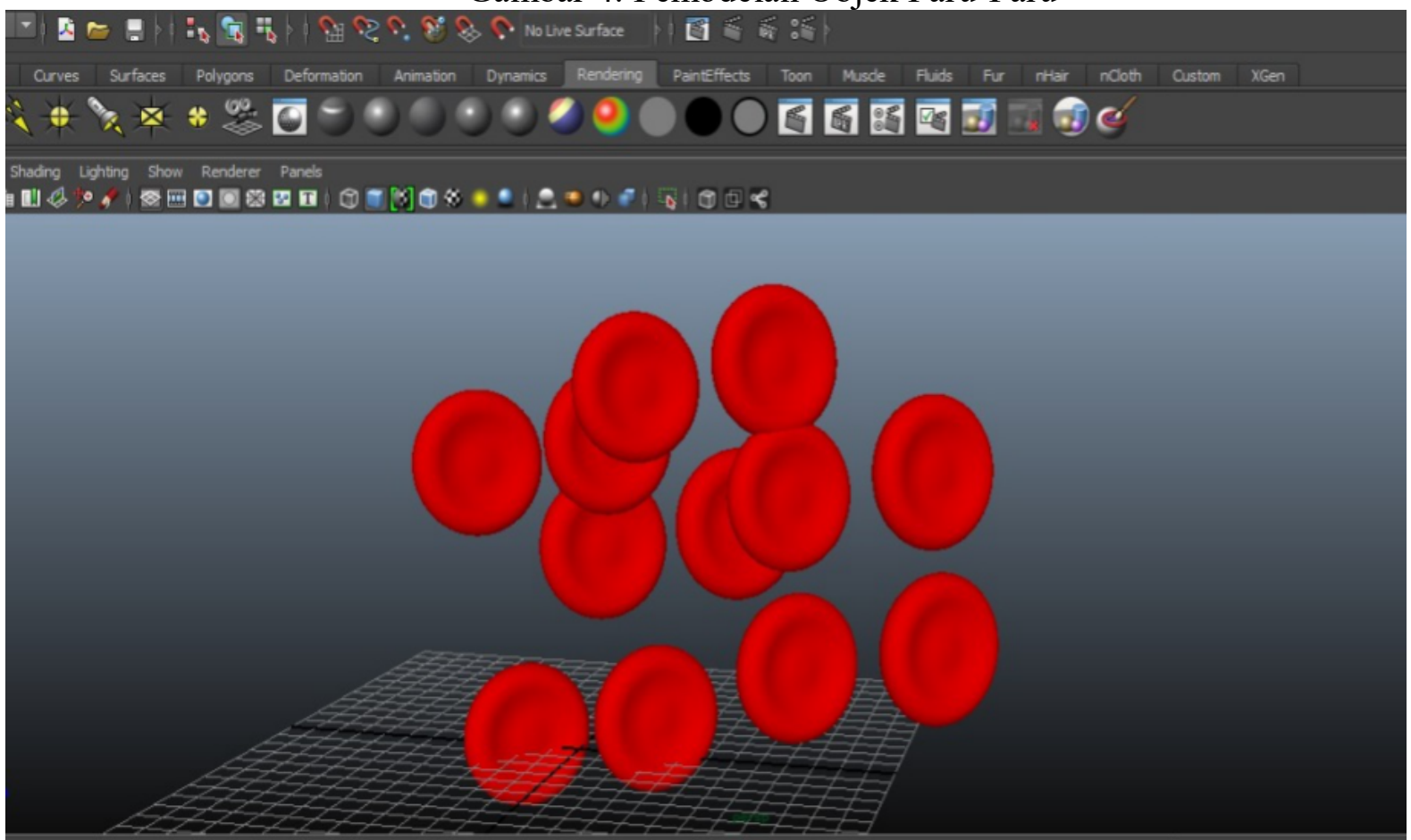

Gambar 5. Pemodelan Objek Sel Darah Merah 


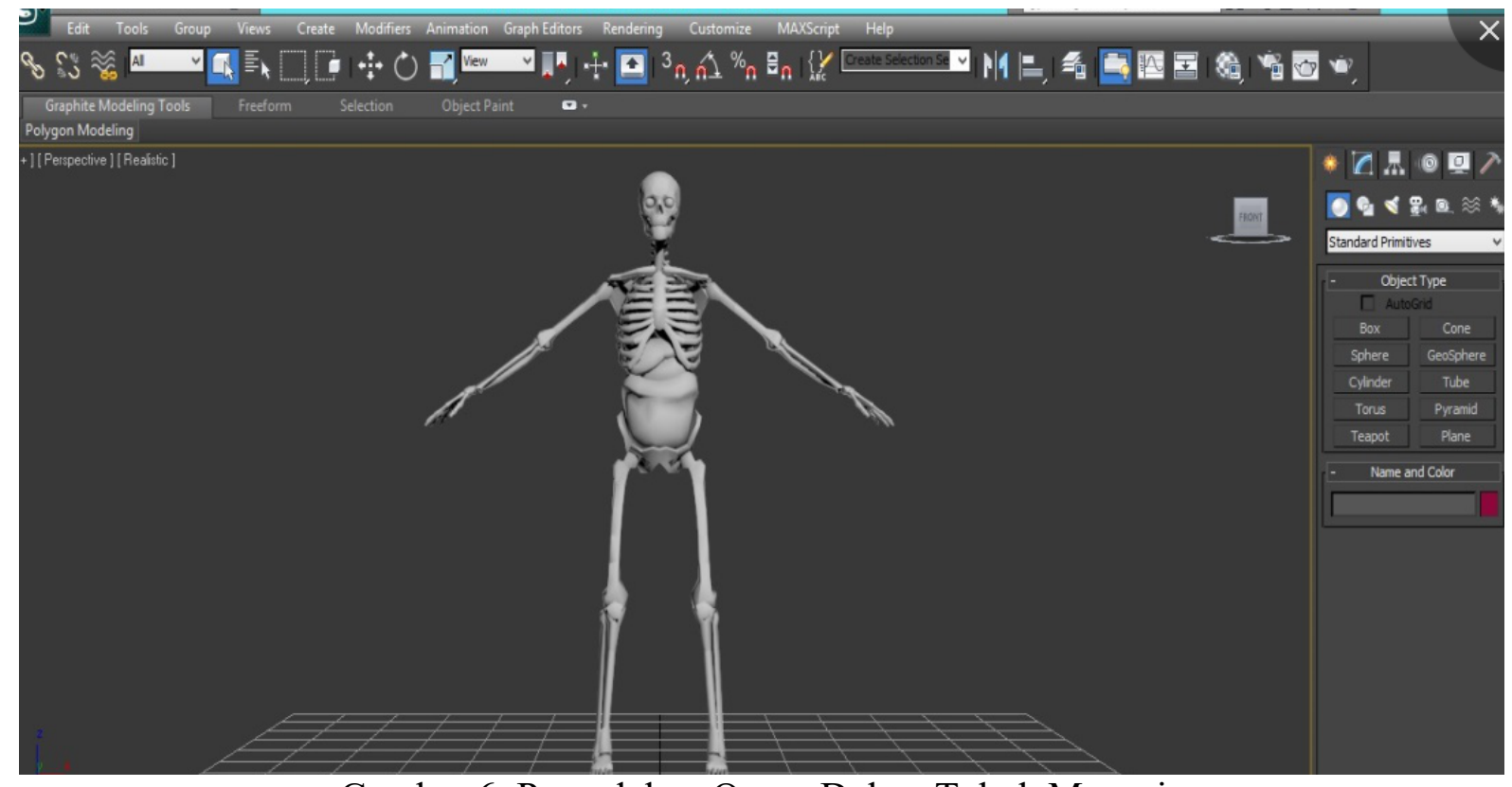

\section{Gambar 6. Pemodelan Organ Dalam Tubuh Manusia}

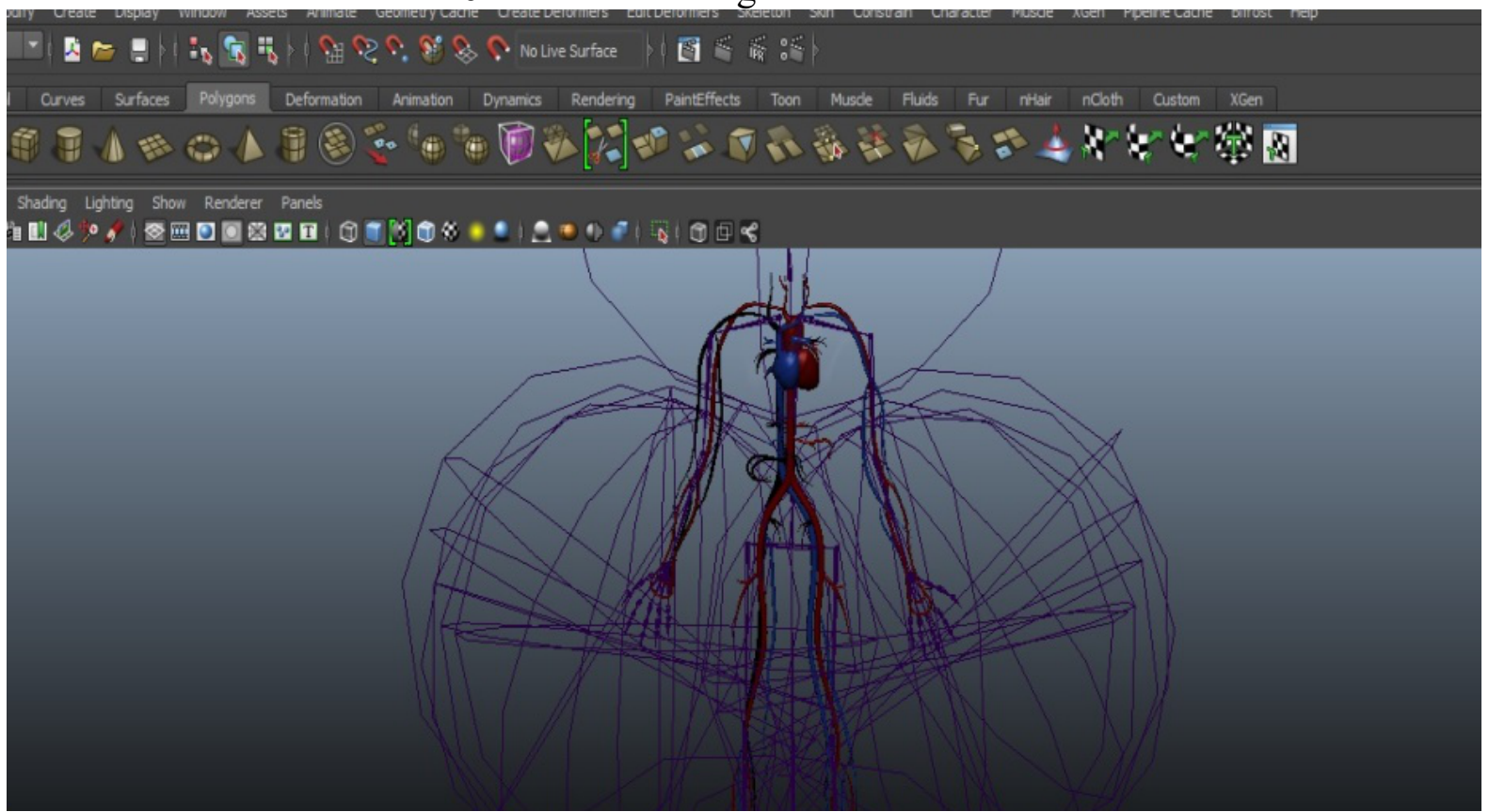

Gambar 7.Pemodelan Pembuluh Darah

\section{HASIL DAN PEMBAHASAN}

3.1 HASIL

User atau pengguna dalam hal ini Guru IPA sekolah dasar yang menggunakan aplikasi ini harus meng-instal aplikasi terlebih dahulu. Setelah itu user dapat masuk ke halaman utama aplikasi, yang berisikan menu utama yaitu fitur-fitur yang sudah tersedia, diantaranya: Jantung, Paru-Paru, SPD (Sistem Peredaran Darah), lalu menekan fitur yang tersedia untuk menjalankan. Form menu utama (Gambar 8) merupakan bagian utama dari menu aplikasi yang akan dilihat user. 


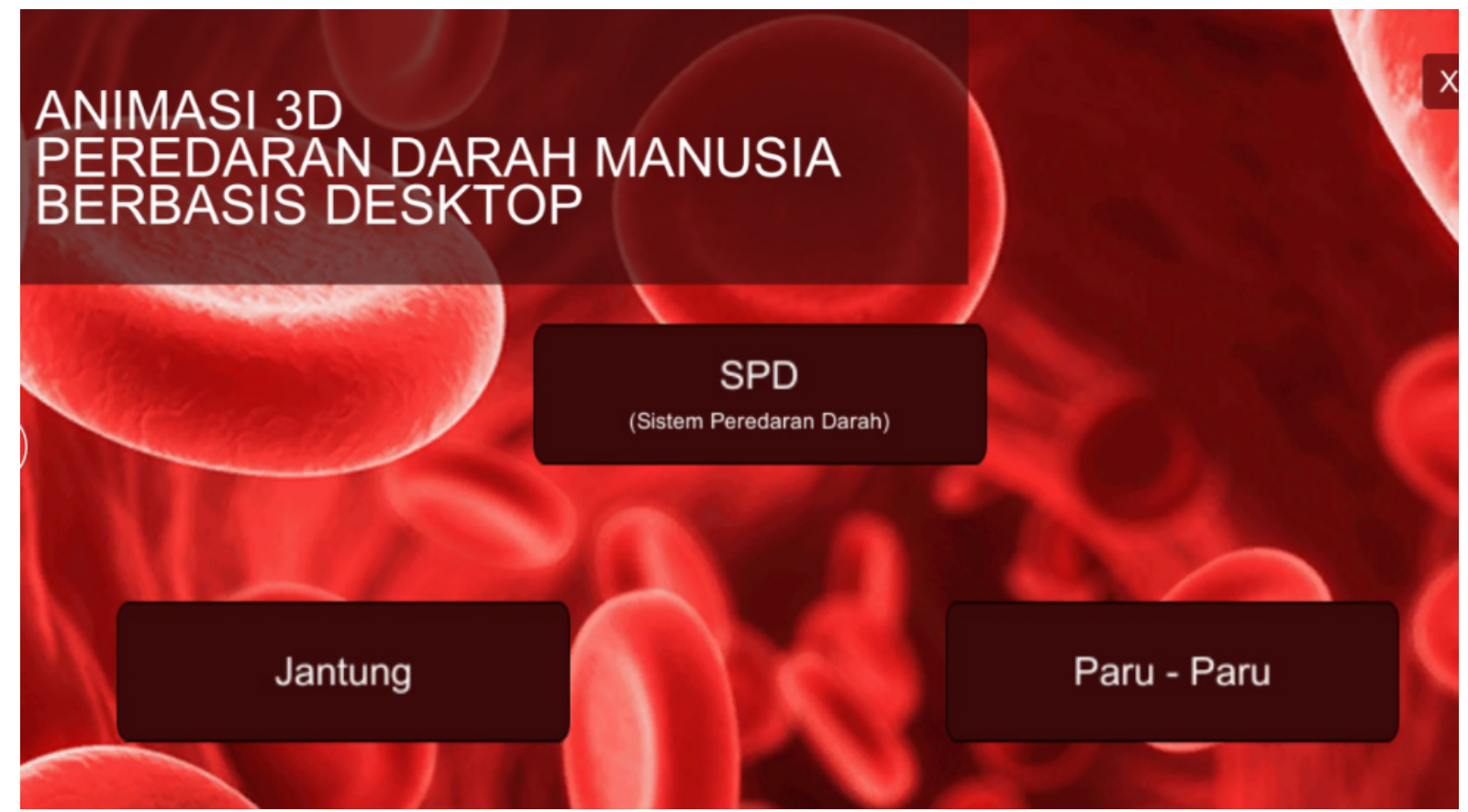

Gambar 8. Tampilan Utama Aplikasi Animasi 3D

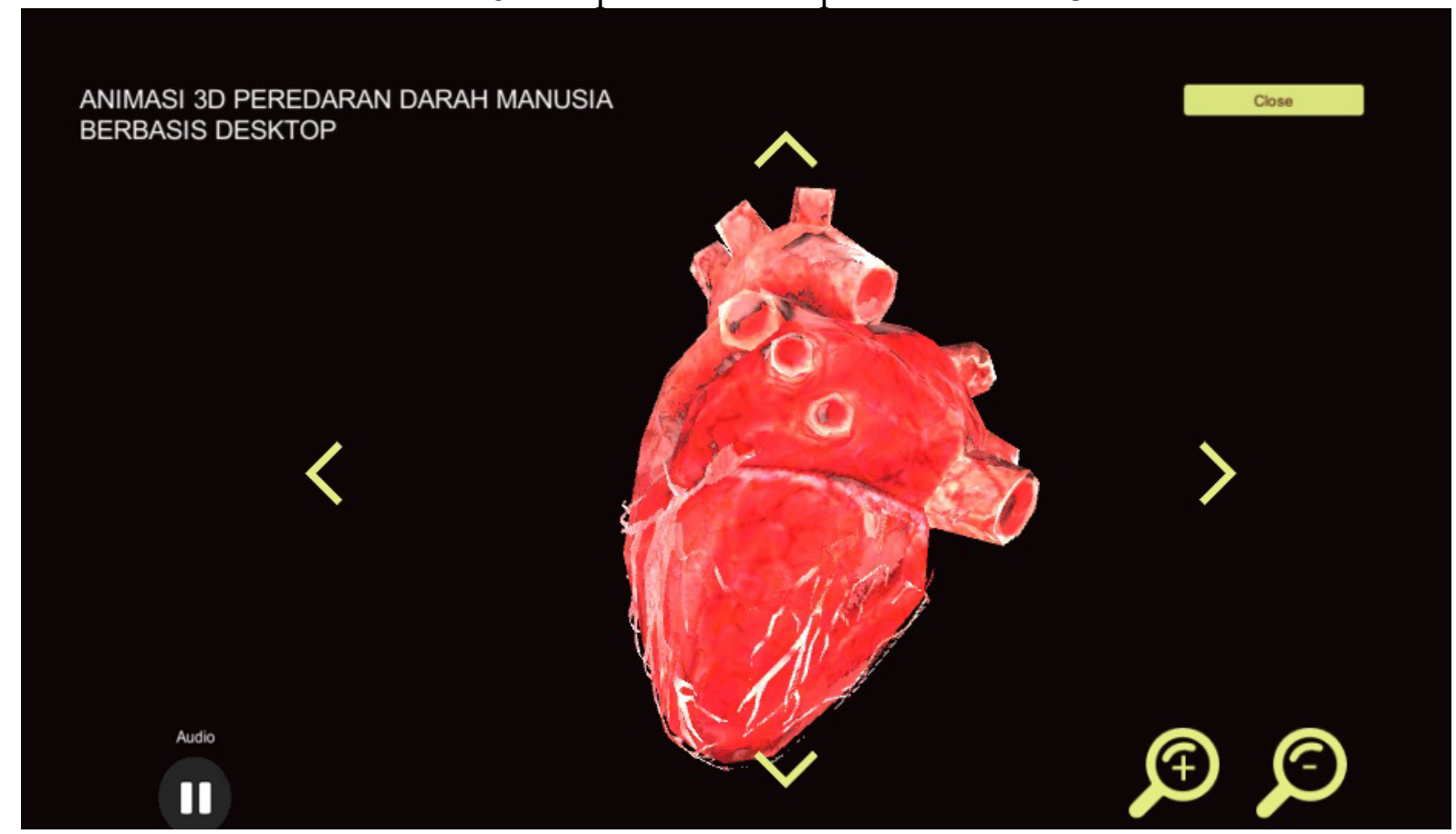

Gambar 9. Tampilan Menu Jantung

Tampilan Menu Jantung (Gambar 9) dapat diketahui secara detail tentang hal-hal yang berkaitan dengan jantung sebagai salah satu organ yang berfungsi dalam sistem peredaran darah. Sedangkan tampilan menu paru-paru (Gambar 10) dapat dilihat secara detail tentang hal-hal yang berkaitan dengan paru-paru sebagai salah satu organ yang berfungsi sebagai sistem peredaran darah. Penjelasan berupa animasi tiga dimensi, audio dan teks sehingga user atau pengguna dapat lebih memahami. Tampilan Pembuluh Darah Manusia, Organ Dalam, dan Peredaran Darah dapat dilihat pada Gambar 11 dan Gambar 12. Pada tampilan tersebut dapat dilihat secara detail sistem peredaran darah pada manusia. 


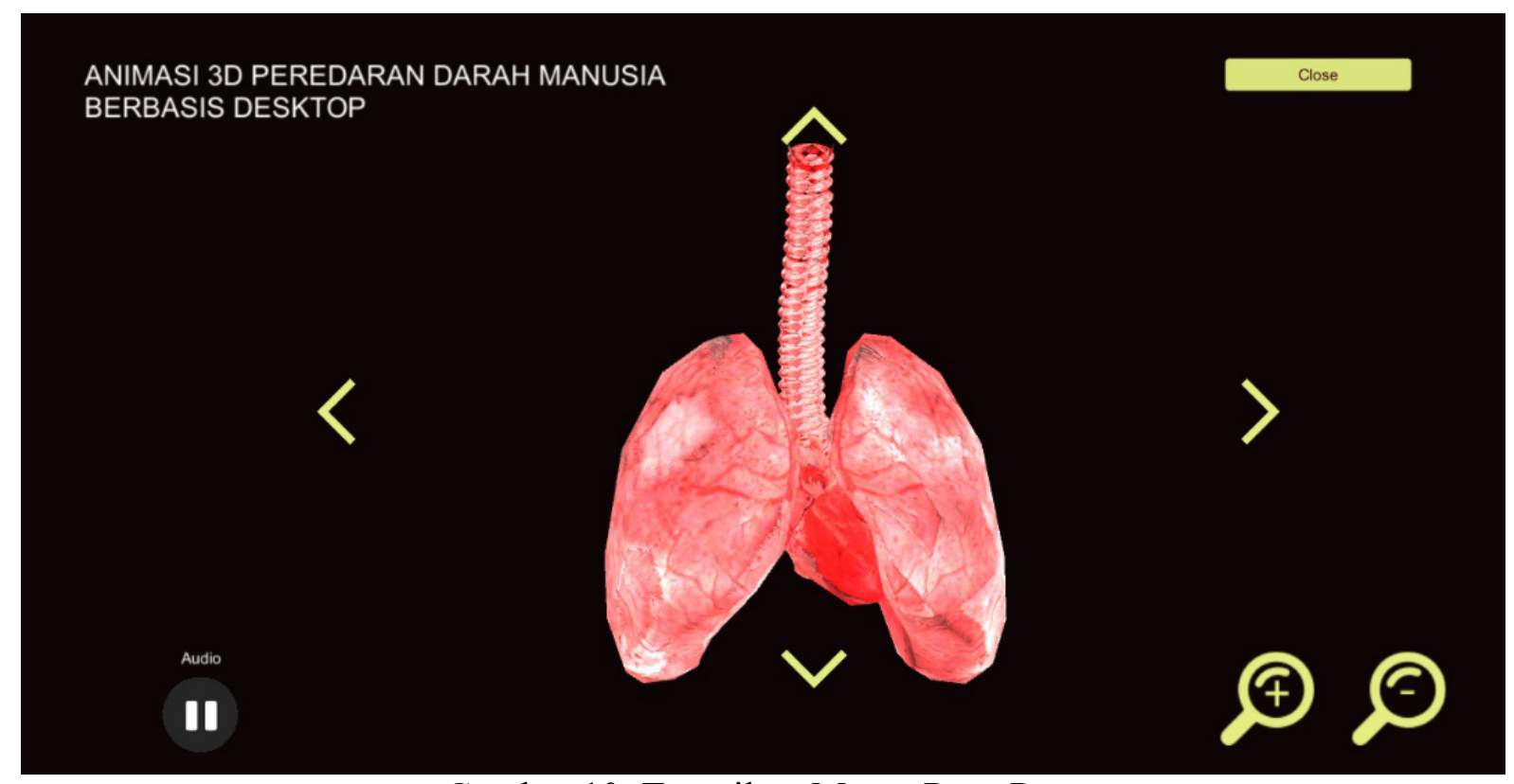

Gambar 10. Tampilan Menu Paru-Paru

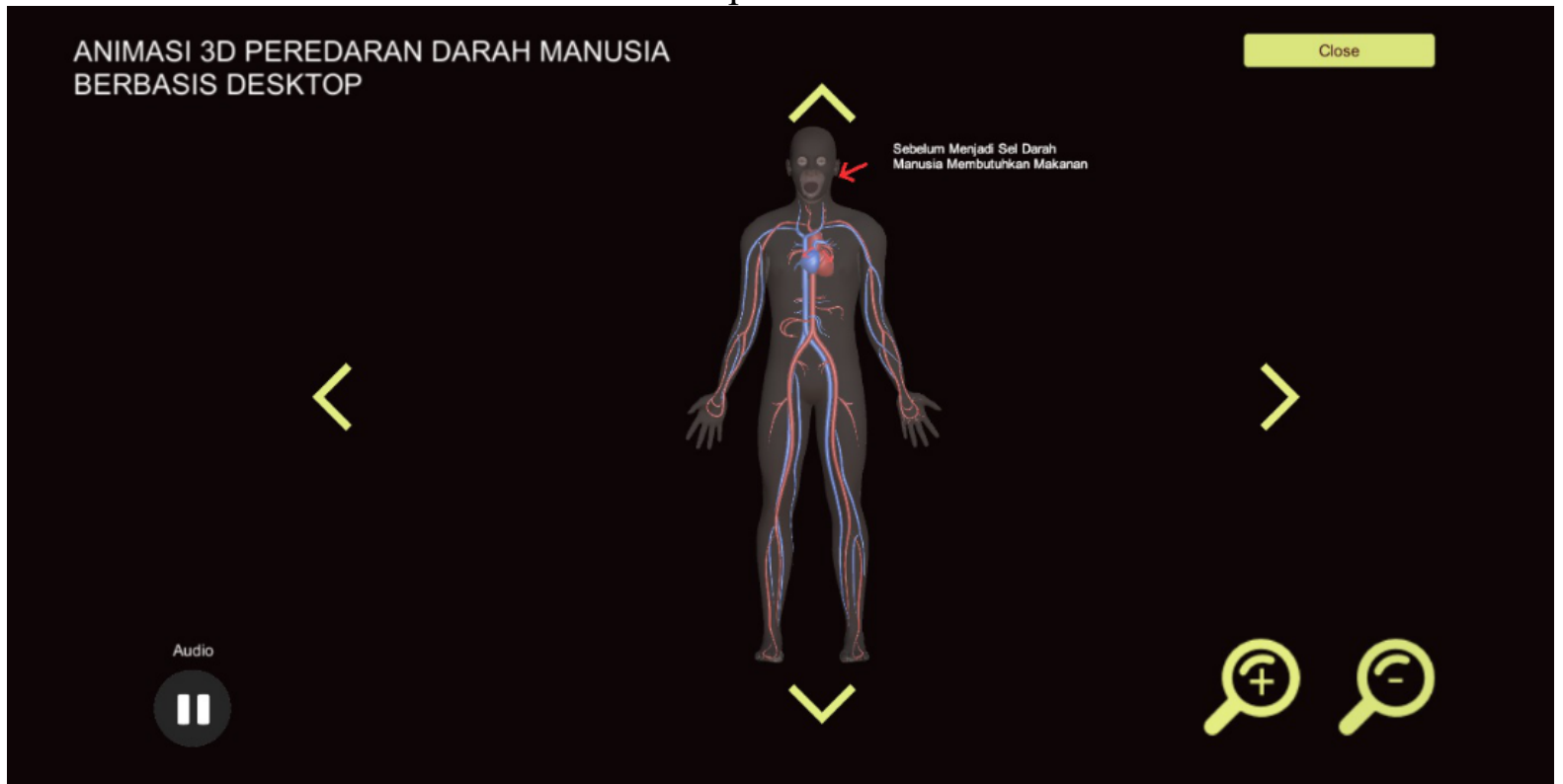

Gambar 11. Tampilan Pembuluh Darah 


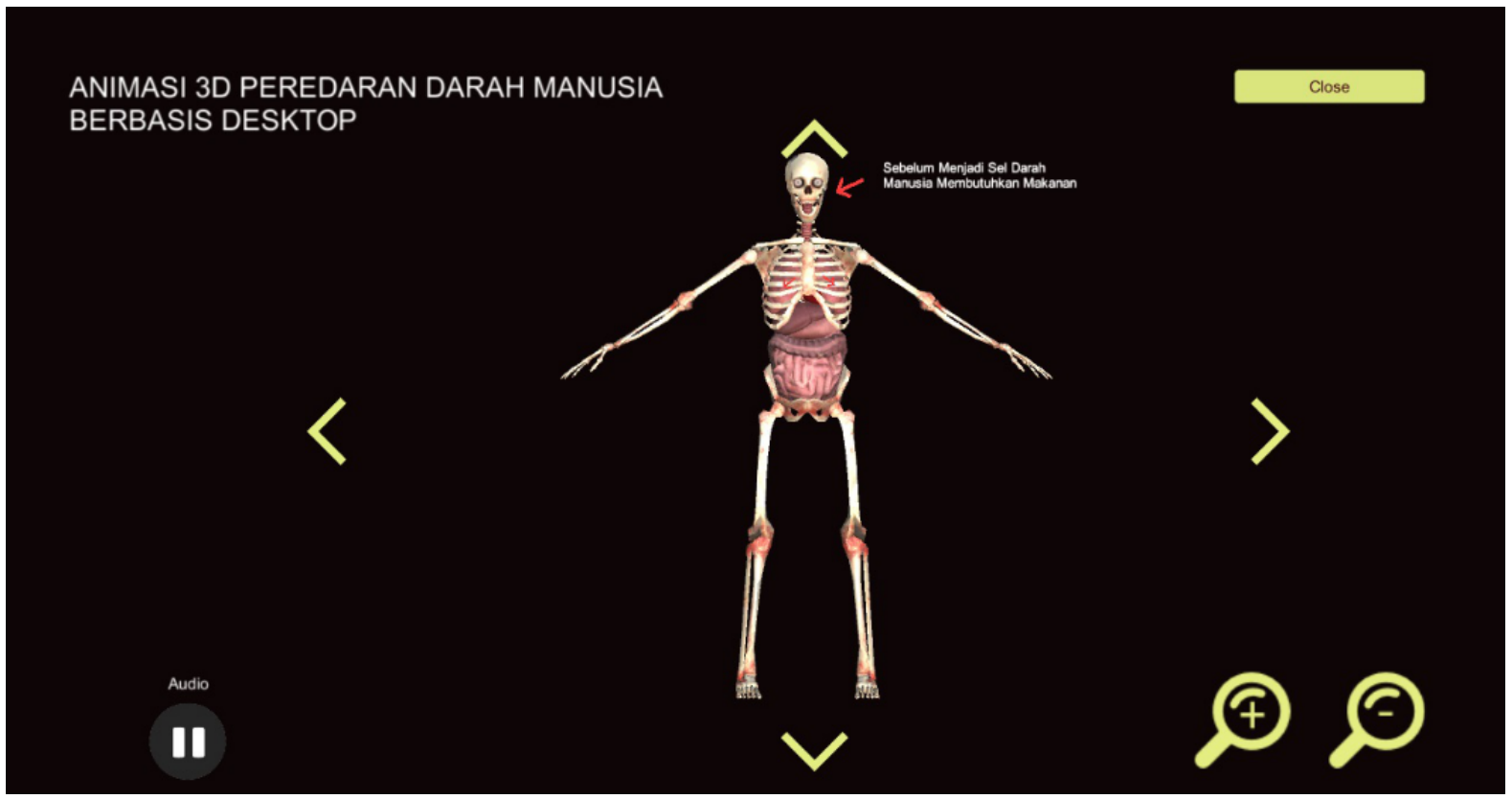

Gambar 12. Organ Dalam Tubuh Manusia

\subsection{Pengujian dan Pembahasan}

Cara kerja aplikasi ini, model animasi tiga dimensi yang terdiri dari beberapa model yaitu jantung, paru-paru, pembuluh darah, dan organ tubuh bagian dalam manusia divisualisasi menjadi video yang berinteraksi dengan user guna mempermudah pengajar atau guru memberikan penjelasan pelajaran IPA (Ilmu Pengetahauan Alam), untuk menjalankan aplikasi ini dapat menggunakan komputer (karena berbasis desktop) untuk menyampaikan materi peredaran darah kepada siswa di sekolah dasar.

\subsubsection{Uji Fungsi}

Uji fungsi Animasi ini dilakukan dengan menjalankan aplikasi yang sudah dibuat. Apakah aplikasi ini sudah berjalan sesuai rencana awal atau belum sesuai dengan rencana. Hasil dari uji fungsi dapat dilihat pada Tabel 3.

Tabel 3. Uji Fungsi

\begin{tabular}{|c|c|c|c|}
\hline No & Rancangan Proses & Hasil Yang Diharapkan & Hasil \\
\hline 1 & Klik "Open" & $\begin{array}{c}\text { Menampilkan Menu } \\
\text { Utama }\end{array}$ & OK \\
\hline 2 & Klik "Fitur Jantung" & $\begin{array}{c}\text { Menampilkan } \\
\text { visualisasi animasi 3D } \\
\text { jantung }\end{array}$ & OK \\
\hline 3 & Klik "Fitur Paru-Paru" & $\begin{array}{c}\text { Menampilkan } \\
\text { visualisasi animasi 3D } \\
\text { paru-paru }\end{array}$ & OK \\
\hline 4 & Klik "Fitur SPD" & $\begin{array}{c}\text { Menampilkan } \\
\text { visualisasi animasi 3D } \\
\text { SPD }\end{array}$ & OK \\
\hline 5 & Klik "Pembuluh Darah" & $\begin{array}{c}\text { Menampilkan animasi } \\
\text { 3D organ bagian dalam }\end{array}$ & OK \\
\hline 6 & Klik "Model Organ Dalam" & $\begin{array}{c}\text { Menampilkan } \\
\text { visualisasi pergerakan } \\
\text { sel darah merah }\end{array}$ & OK \\
\hline 7 & Animasi 3D Interaktif & $\begin{array}{c}\text { Menampilkan animasi } \\
\text { 3D interaktif }\end{array}$ & OK \\
\hline
\end{tabular}




\begin{tabular}{|c|c|c|c|}
\hline 8 & Klik "Close" & $\begin{array}{c}\text { Kembali ke tampilan } \\
\text { utama }\end{array}$ & OK \\
\hline 9 & Klik "Tombol Play" & Menjalankan audio & OK \\
\hline 10 & Klik "Tombol Pause" & Menghentikan audio & OK \\
\hline 11 & Klik "Tombol Zoom In" & Memperbesar tampilan & OK \\
\hline 12 & $\begin{array}{c}\text { Mengarahkan kursor ke model } \\
\text { animasi }\end{array}$ & Menampilkan teks & OK \\
\hline 13 & Klik "Exit" & Keluar dari aplikasi & OK \\
\hline
\end{tabular}

Keterangan:

OK: Berhasil

No: Gagal

\subsubsection{Uji Coba Pengguna}

Hasil pengujian menggunakan kuesioner dengan responden berjumlah sepuluh orang yang merupakan guru sekolah dasar di 10 Sekolah Dasar yang berbeda. Hasil uji coba pengguna dapat dilihat pada Tabel 4.

Tabel 4. Hasil Uji Coba Pengguna

\begin{tabular}{|c|c|c|c|c|c|}
\hline \multirow{2}{*}{ Pertanyaan } & \multicolumn{5}{|c|}{ Penilaian } \\
\cline { 2 - 6 } & SB & B & C & K & SK \\
\hline 1 & 10 & 0 & 0 & 0 & 0 \\
\hline 2 & 9 & 1 & 0 & 0 & 0 \\
\hline 3 & 10 & 0 & 0 & 0 & 0 \\
\hline 4 & 10 & 0 & 0 & 0 & 0 \\
\hline 5 & 9 & 1 & 0 & 0 & 0 \\
\hline 6 & 10 & 0 & 0 & 0 & 0 \\
\hline 7 & 8 & 2 & 0 & 0 & 0 \\
\hline 8 & 10 & 0 & 0 & 0 & 0 \\
\hline 9 & 10 & 0 & 0 & 0 & 0 \\
\hline 10 & 0 & 10 & 0 & 0 & 0 \\
\hline Total & 86 & 14 & 0 & 0 & 0 \\
\hline
\end{tabular}

Mendapatkan hasil jawaban sebagai berikut:

Sangat baik: 86

Baik: 14

Cukup: 0

Kurang: 0

Sangat Kurang: 0

Dengan perhitungan menggunakan skala Likert dan intrepretasi skor nilai pada kuosioner, maka didapatkan penyelesaian hasil sebesar 97,2\% dan hasil tersebut masuk dalam kategori sangat baik (menggunakan perhitungan rumus interval), sehingga didapatkan kesimpulan bahwa aplikasi animasi tiga dimensi sistem peredaran darah ini dapat diterapkan dan dapat membantu Guru dalam memberikan pembelajaran siswa di sekolah dasar.

\section{Kesimpulan}

Kesimpulan yang diperoleh dari hasil analisa pengujian aplikasi animasi tiga dimensi peredaran darah manusia menggunakan teknik high poly dan particle system ini adalah sebagai berikut : 
1. Mempermudah para pengajar atau guru memberikan penjelasan mengenai peredaran darah manusia kepada siswa di sekolah dasar.

2. Hasil uji fungsi aplikasi animasi tiga dimensi menggunakan komputer dapat berjalan sesuai dengan fungsinya.

3. Pengujian menggunakan kuesioner dan dihitung dengan metode skala likert adalah $97,2 \%$, maka dapat disimpulkan bahwa pengujian menggunakan kuesioner termasuk dalam kriteria "Sangat Baik".

\section{DAFTAR PUSTAKA}

[1] Utami, D. (2007). Animasi Dalam Pembelajaran. Majalah Ilmiah Pembelajaran, 7(1).

[2] Gunawan, Bambi Bambang. (2013). Nganimasi Bersama Mas Be!. Elex Media Komputindo. Jakarta.

[3] IDS Education. Memahami Lebih Dalam Pengertian Animasi 3D. online:https://idseducation.com/articles/memahami-lebih-dalam-pengertian-animasi-3d/. Diakses 2 September 2018.

[4] Hendi Hendratman. (2014). Computer Graphic Design. Penerbit Informatika. Bandung.

[5] Arjun Patel. Differences Between High Poly Vs Low Poly 3D Models. Online: https://medium.com/@arjun07/differences-between-high-poly-vs-low-poly- 3d-models348cab56e82e. Diakses 2 September 2018. 